\title{
Identical Viral Genetic Sequence Found in Black Flies (Simulium bivittatum) and the Equine Index Case of the 2006 U.S. Vesicular Stomatitis Outbreak
}

\author{
Barbara S. Drolet ${ }^{1} * \mathbb{D}^{\mathbb{D}}$, Will K. Reeves ${ }^{2}$, Kristine E. Bennett ${ }^{3}$, Steven J. Pauszek ${ }^{4}$, Miranda R. Bertram ${ }^{5} \mathbb{( D}$ \\ and Luis L. Rodriguez 5 (D)
}

1 Arthropod-Borne Animal Diseases Research Unit, Center for Grain and Animal Health Research, Agricultural Research Service, Unites States Department of Agriculture, Manhattan, KS 66502, USA

2 Biological Regulatory Services, Animal and Plant Health Inspection Service, United States Department of Agriculture, Fort Collins, CO 80526, USA; will.k.reeves@usda.gov

3 Energy Institute, Colorado State University, Fort Collins, CO 80523, USA; kristine.bennett@colostate.edu

4 Foreign Animal Disease Diagnostic Laboratory, Plum Island Animal Disease Center, National Veterinary Services Laboratories, Animal and Plant Health Inspection Service, United States Department of Agriculture, Orient Point, NY 11957, USA; steve.pauszek@usda.gov

5 Foreign Animal Disease Research Unit, Plum Island Animal Disease Center, Agricultural Research Service, Unites States Department of Agriculture, Orient Point, NY 11957, USA; miranda.bertram@usda.gov (M.R.B.); luis.rodriguez@usda.gov (L.L.R.)

* Correspondence: barbara.drolet@usda.gov

\section{check for} updates

Citation: Drolet, B.S.; Reeves, W.K.; Bennett, K.E.; Pauszek, S.J.; Bertram, M.R.; Rodriguez, L.L. Identical Viral Genetic Sequence Found in Black Flies (Simulium bivittatum) and the Equine Index Case of the 2006 U.S. Vesicular Stomatitis Outbreak. Pathogens 2021, 10, 929. https://doi.org/10.3390/ pathogens10080929

Academic Editor: Magda Dunowska

Received: 18 June 2021

Accepted: 21 July 2021

Published: 23 July 2021

Publisher's Note: MDPI stays neutral with regard to jurisdictional claims in published maps and institutional affiliations.

Copyright: (C) 2021 by the authors Licensee MDPI, Basel, Switzerland. This article is an open access article distributed under the terms and conditions of the Creative Commons Attribution (CC BY) license (https:/ / creativecommons.org/licenses/by/ $4.0 /)$.
Abstract: In 2006, vesicular stomatitis New Jersey virus (VSNJV) caused outbreaks in Wyoming (WY) horses and cattle after overwintering in 2004 and 2005. Within two weeks of the outbreak onset, 12,203 biting flies and 194 grasshoppers were collected near three equine-positive premises in Natrona County, WY. Insects were identified to the species level and tested by RT-qPCR for VSNJV polymerase (L) and phosphoprotein (P) gene RNA. Collected dipterans known to be competent for VSV transmission included Simulium black flies and Culicoides biting midges. VSNJV L and P RNA was detected in two pools of female Simulium bivittatum and subjected to partial genome sequencing. Phylogenetic analysis based on the hypervariable region of the P gene from black flies showed $100 \%$ identity to the isolate obtained from the index horse case on the same premises. This is the first report of VSNJV in S. bivittatum in WY and the first field evidence of possible VSV maintenance in black fly populations during an outbreak.

Keywords: vesicular stomatitis virus; horse; black fly; Simulium bivittatum

\section{Introduction}

Vesicular stomatitis (VS) is a vector-borne, zoonotic disease caused by the RNA virus vesicular stomatitis virus (VSV), a Vesiculovirus in the family Rhabdoviridae, which primarily affects horses, cattle, and swine with clinical signs that include transient fever, excessive salivation, and lesions in the oral cavity, on the lips, nose, coronary bands, and teats of livestock $[1,2]$. Because these lesions in cattle and swine resemble those caused by foot and mouth disease virus, VS is designated as a reportable disease resulting in economic losses primarily due to animal quarantines and trade restrictions [3,4]. Incursions of VSV into the U.S. from endemic regions in southern Mexico occur sporadically at 5-10-year intervals, resulting in single or multi-year outbreaks, presumably by overwintering through an as yet unknown mechanism [3].

Active pathogen-based annual surveillance of VS in the U.S. is limited. Accredited veterinarians are required to immediately report cases of suspected vesicular lesions to state and federal animal health officials. All livestock with reported lesions are tested for VSV as part of the vesicular diseases rule-out process. During years where VS does not 
occur, the U.S. Department of Agriculture (USDA), Animal and Plant Health Inspection Service (APHIS) typically tests 150-200 premises nationwide in response to reported lesions that are determined to be something other than VS. In years when VS outbreaks have been confirmed, reports of suspected vesicular lesions increase significantly, with USDA, APHIS testing 800-1000 premises nationwide, although a proportion of those reports are determined diagnostically to be something other than VS. The only VS testing performed on non-clinical livestock is for the purpose of export to other countries, which varies widely from year to year and depends on the testing requirements of the receiving country. The use of seroprevalence testing to determine outbreak status or transmission rates is of limited value due to persisting antibodies in exposed animals. Specifically, previous exposure of horses during a single VS outbreak year resulted in VS-positive horses maintaining antibody titers for 10-12 years [5,6]. For these reasons, USDA policy is to only perform VS testing on non-clinical animals if required for export. Thus, the first report of lesions, with positive confirmatory PCR swab testing, is reported as the first VS-positive premises for a specific region or state. Confirmed positive and suspect premises are quarantined for at least 14 days from the onset of lesions in the last affected animal on the premises [7].

During outbreaks, viral transmission can occur within herds by direct contact between infected animals, which shed copious amounts of virus in lesions and saliva, or by fomites [2,8]. Several insect species have been incriminated as both mechanical and biological vectors which acquire VSV from blood, lesions, or saliva [9-11]. They are believed to play an important role in the transmission of virus within and between herds, especially when quarantines and stop-movement measures are in place [11-20]. During U.S. outbreaks, VSV has been isolated from several Dipteran species including mosquitoes (Aedes spp.) [21], biting midges (Culicoides spp.) [22,23], black flies (Simulium spp.) [10,20], and from sand flies (Lutzomyia shannoni) on Ossabaw Island, GA where VS was endemic until feral swine populations were removed [12,24-26]. Grasshoppers (Melanoplus spp.) were shown in laboratory settings to become infected by eating VSV-contaminated pasture plants [27], amplify the virus, and transmit it to cattle that ingest them [15]; however, there are no reports of field-collected grasshoppers during outbreaks.

In addition to field evidence for vector incrimination, experimental studies with colonized and wild-caught Simulium black flies have demonstrated VS New Jersey virus (VSNJV) replication [13,28], VS Indiana virus (VSINV) replication [29], and bite transmission of VSNJV [14,30,31]. Simulium bivittatum, a common black fly species across the western U.S., produces several generations over the vector season. Eggs, larvae, and pupae develop in flowing fresh water; only the adult stage is terrestrial [32,33]. Adults emerge and immediately seek food sources and mates, dispersing less than $5 \mathrm{~km}$ from their origin at first, but females can disperse hundreds of $\mathrm{km}$ during their 10- to 35-day average lifespan to find hosts for blood meals and suitable habitat for oviposition [32]. Many Simulium spp., including S. bivittatum, feed on livestock and large animals in the ears, on other sparsely-haired areas of the head, and on the underbelly [32]. They are significant pests of horses [34,35].

A three-year U.S. VS outbreak in horses and cattle occurred between 2004 (NM, TX, CO; 294 premises in 43 counties), 2005 (NM, AZ, TX, UT, CO, WY, NE, MT, ID; 445 premises in 69 counties), and 2006 (WY; 13 premises in 3 counties) [36-38]. State-imposed quarantines were lifted in WY on 28 December, 2005 [39]. The index case for 2006 was a horse with clinical lesions reported nine months later on 13 August [38,39] in Natrona County, WY, with 29 clinically normal horses and 25 clinically normal cattle also on the premises. Sequencing and phylogenetic analysis revealed a shared genotype from virus isolated in 2004 and 2005 [40], and a second shared genotype from virus collected in 2005 and 2006 [38]. Phylogeographic data support the virus overwintering in NM, TX, and CO from 2004-2005 [40] and in WY from 2005-2006 [39].

In the absence of clinically infected livestock between multiyear outbreak seasons, and with no known mammalian wildlife reservoir for VSV, insects have been suggested as likely overwintering reservoirs [12,41-43]. To examine the insect species possibly involved 
in maintaining the outbreak and potential insect sources for overwintering of the virus in WY between the last resolved case in December 2005 and the index case in August of 2006 , biting flies were caught in light traps placed on the outbreak premises 11 days after the first clinical case was reported. Grasshoppers near traps were also collected by hand netting. Collections were in late August, less than a month prior to first freeze dates in Natrona County, WY (www.crh.noaa.gov/riw/climate/clm/lcdcpr.php accessed on 3 June 2021). Insects collected were likely the last generation for the year and would have either overwintered as adults or laid potentially infected eggs. All biting flies and grasshoppers were tested for VSNJV by RT-qPCR and virus isolation in cell culture, and sequencing was attempted for positive samples.

\section{Results}

\subsection{Collection Sites}

Information on the geographic location (latitude, longitude) of the VSNJV-infected premises was provided by USDA, APHIS. The 2006 VSNJV outbreak in the U.S. started in Natrona County, WY with the first reported lesion in a horse on 13 August. Swabs of lesions and blood samples were obtained by the attending veterinarian and submitted to the USDA, APHIS, National Veterinary Services Laboratories (NVSL; Ames, IA). VSNJV was confirmed in lesion swabs by virus isolation and VSV antibody was confirmed by cELISA. The VS-compatible clinical signs and the presence of virus met the definition to classify this horse as the index case for the nation. The isolate was obtained and the whole genome was sequenced at the USDA, Agricultural Research Service (ARS), Plum Island Animal Disease Center (PIADC) in Orient Point, NY (GenBank, Dec. 2020, MT094085.1) [44]. During the 2005 outbreak, Natrona County reported only two cases, with lesion onset dates of 30 October and 6 November. Thus, the last infected premises for WY occurred nine months earlier and was located four miles west of the first case in 2006. By 20 August, three positive premises, of what would ultimately be a total of eight in the county, had been confirmed. Permissions were received from property owners of the three premises for insect collection efforts, which began on 23 August.

\subsection{Detection of VSV RNA in Insect Collections}

A total of 12,203 biting flies and 193 grasshoppers were collected from three premises in one county of WY during the VS outbreak and sorted by species. Biting fly species collected included Aedes, Culex, and Culiseta mosquitoes, Stomoxys calcitrans and Hematobia irritans biting flies, Culicoides biting midges, and Simulium black flies (Table 1). Additionally, grasshopper species collected included Melanoplus gladstoni, M. fermurrubrum, and $M$. sanguinipes, Spharagemoh collare, Opeia spp., Chorthippus curtipennis, and Paropomala wyomingensis. No VSNJV RNA was detected by RT-qPCR in any of the mosquitoes, the Stomoxys calcitrans or Hematobia irritans biting flies, the Culicoides biting midges (C. sonorensis and C. steliffer), nor in any of the grasshoppers.

Four Simulium black fly species were collected: S. arcticum, S. bivittatum, S. griseum, and S. tribulatum. Of these, two pools of $S$. bivittatum from one trap set in the east Casper pasture near the North Platte River were positive for both the polymerase (L) and phosphoprotein (P) genes of VSNJV (Table 1). Flies did not have a blood meal at the time of collection so viral RNA detection indicates an active infection in the insect, as opposed to detection of virus from an infectious meal in the gut. The trap was located near an outdoor hay bailer in a large pasture that held six horses with no vesicular lesions. This pasture was located approximately 200 yards from an enclosure where the clinically infected horse was housed. The premises was four miles east of the last positive premises in 2005. The lesion onset date was reported to APHIS as 13 August 2006 (11 days prior to insect collections), at which time a vesicle swab was sent to USDA, APHIS, NVSL for diagnostic evaluation of a suspected VSV infection and eventually sent to PIADC for phylogenetic analyses. Virus isolation attempts with the remaining original RT-qPCR-positive black fly homogenate samples by passage in Vero cell cultures were unsuccessful. 
Table 1. Insect species collected from three sites in Natrona County, Wyoming in August of 2006.

\begin{tabular}{|c|c|c|c|c|}
\hline Collection Site & Date & Identification & $\begin{array}{l}\text { Number of } \\
\text { Females }\end{array}$ & $\begin{array}{l}\text { VSNJV PCR+ } \\
\text { Pools/Total }\end{array}$ \\
\hline \multirow[t]{15}{*}{$\begin{array}{c}\text { East Casper pasture } \\
\text { near North Platte River }\end{array}$} & 24-25 August 2006 & & & \\
\hline & & Aedes dorsalis & 4789 & $0 / 96$ \\
\hline & & Ae. melanimon & 7 & $0 / 1$ \\
\hline & & Ae. nigramaculis & 11 & $0 / 1$ \\
\hline & & Ae. vexans & 89 & $0 / 2$ \\
\hline & & Culex tarsalis & 59 & $0 / 2$ \\
\hline & & Culiseta inornata & 311 & $0 / 7$ \\
\hline & & Culicoides crepuscularis & 21 & $0 / 1$ \\
\hline & & C. sonorensis & 666 & $0 / 14$ \\
\hline & & C. steliffer & 28 & $0 / 1$ \\
\hline & & Hematobia irritans & 2 & $0 / 1$ \\
\hline & & $\begin{array}{l}\text { Simulium arcticum } \\
\text { complex }\end{array}$ & 230 & $0 / 5$ \\
\hline & & S. bivittatum & 3108 & $2 / 63$ \\
\hline & & S. griseum & 590 & $0 / 12$ \\
\hline & & S. tribulatum/S. vittatum & 2 & $0 / 1$ \\
\hline
\end{tabular}

\section{South Casper}

field near

artesian spring
23-25 August 2006

$\begin{array}{ccc}\text { Ae. dorsalis } & 2 & 0 / 1 \\ \text { Cx. tarsalis } & 22 & 0 / 1 \\ \text { C. sonorensis } & 218 & 0 / 5 \\ \text { S. arcticum complex } & 4 & 0 / 1 \\ \text { S. bivittatum } & 84 & 0 / 2 \\ \text { S. griseum } & 46 & 0 / 1\end{array}$

\begin{tabular}{|c|c|c|c|}
\hline $\begin{array}{c}\text { Southeast Casper Farm } \\
\text { near creek }\end{array}$ & 24-25 August 2006 & & \\
\hline & Ae. dorsalis & 859 & $0 / 18$ \\
\hline & Ae. melanimon & 303 & $0 / 7$ \\
\hline & Ae. nigramaculis & 50 & $0 / 1$ \\
\hline & Ae. vexans & 74 & $0 / 2$ \\
\hline & $C x$. tarsalis & 196 & $0 / 4$ \\
\hline & Cs. inornata & 37 & $0 / 1$ \\
\hline & C. sonorensis & 4 & $0 / 1$ \\
\hline & H. irritans & 2 & $0 / 1$ \\
\hline & S. arcticum complex & 90 & $0 / 2$ \\
\hline & S. bivittatum & 33 & $0 / 1$ \\
\hline & S. griseum & 14 & $0 / 1$ \\
\hline & S. tribulatum/S. vittatum & 251 & $0 / 5$ \\
\hline & Stomoxys calcitrans & 1 & $0 / 1$ \\
\hline
\end{tabular}

Pools were tested for VSNJV polymerase and phosphoprotein gene RNA by RT-qPCR. Two pools of Simulium bivittatum were positive for both genes (bold). 


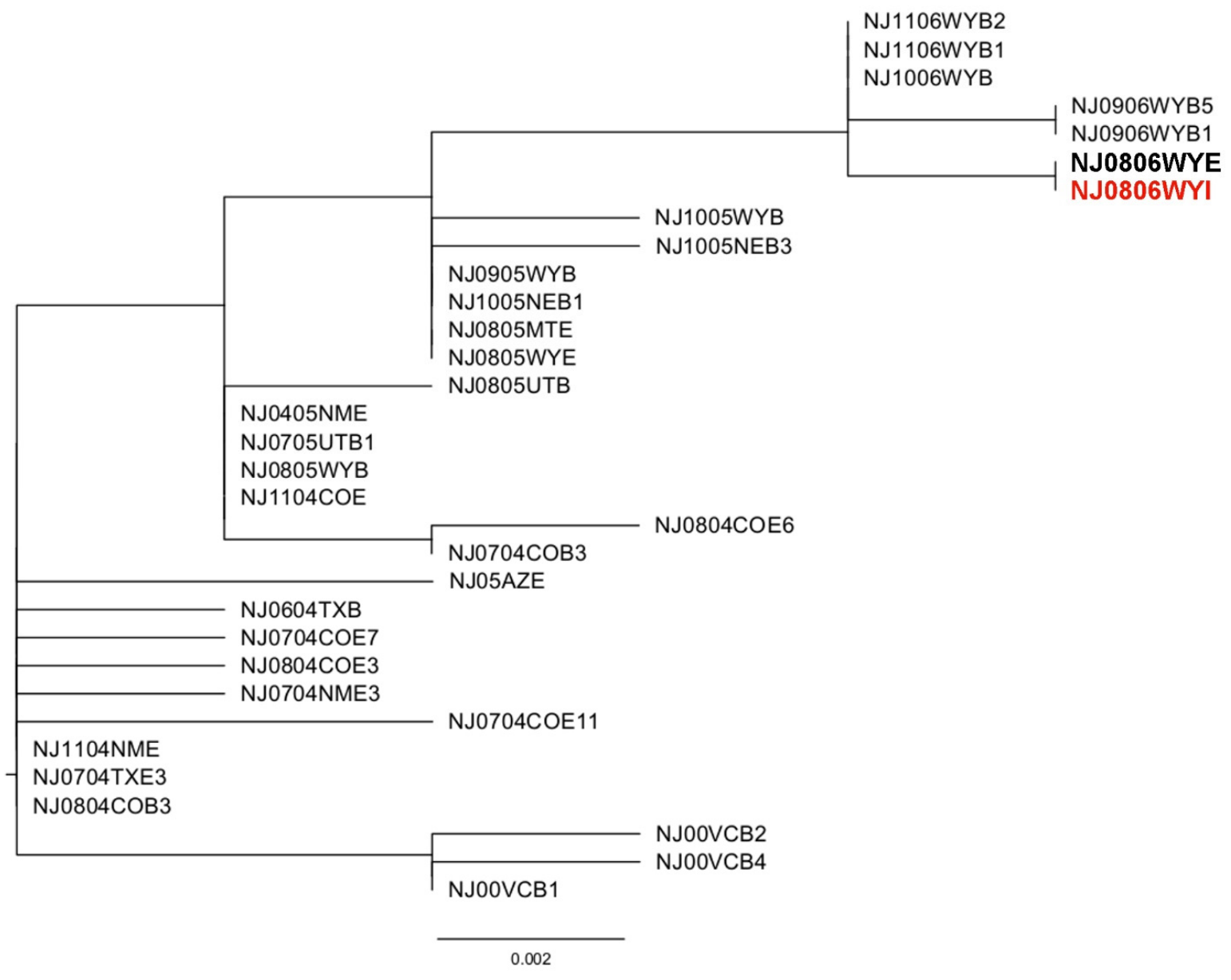

Figure 1. Maximum-likelihood analysis of vesicular stomatitis New Jersey virus (VSNJV) isolates from the 2004-2006 U.S. outbreak deduced from the phosphoprotein gene hypervariable region. Tree was rooted with a closely related viral lineage from an endemic region in Mexico (Veracruz). Metadata is contained in each sequence name: serotype (NJ: New Jersey), month (when available), year, state (two letter code for U.S. states, VC: Veracruz, Mexico), host (B: bovine, E: equine, I: insect), and isolate number (if more than one with the same name). Representative sequences of each previously identified distinct strain are included in the analysis. The 2006 black fly VSNJV isolate NJ0806WYI (bold red), collected 24-25 August, is $100 \%$ identical to NJ0806WYE (bold), collected 13 August from the equine index case on the same premises.

\subsection{Sequencing and Phylogenetic Analysis of VSNJV-Positive Black Flies}

Complete sequence coverage of the $450 \mathrm{nt}$ hypervariable region of the $\mathrm{P}$ gene was obtained from one of the two RT-qPCR VSV-positive S. bivittatum pools (NJ0806WYI). Phylogenetic analysis with sequences from the 2004-2006 U.S. outbreak showed the NJ0806WYI black fly sequence formed a monophyletic clade with the other six sequences collected in 2006 and was closely related to sequences collected in 2005 in the same region (Figure 1). The NJ0806WYI black fly pool, collected on 24-25 August 2006, was $100 \%$ identical across the $450 \mathrm{nt}$ hypervariable region to NJ0806WYE (GenBank MT094085.1), the isolate recovered from the equine index case sample collected on 13 August 2006 from the same premises. It was $99.3 \%$ identical ( $3 \mathrm{nt}$ differences over the $450 \mathrm{nt}$ sequence) to two 2005 Wyoming isolates: a horse (NJ0805WYE) and a cow (NJ0905WYB) from the previous year's outbreak. Further phylogenetic characterizations of the 2004-2006 U.S. outbreak were reported previously $[38,40]$. 


\section{Discussion}

A diverse number of arthropod species have been identified as confirmed or suspected vector species for VSV [11]. Both S. vittatum and S. notatum have been demonstrated as vectors of VSV under laboratory conditions $[13,29,45]$. Our data support the previous evidence of Simulium spp. as vectors of VSNJV. In addition, VSNJV has been isolated from S. bivittatum, S. vittatum/S. tribulatum, and undetermined Simulium (Psilopelmia) spp. from VS outbreaks in Colorado [10,20]. Additional incriminated vectors in the U.S. include $C$. sonorensis biting midges [16-19] and Lutzomyia shannoni sand flies [26]. Suspected vectors include C. stellifer [23] and migratory grasshoppers [15,27]. These insects were identified in the collections, but none were positive for VSNJV.

We detected VSNJV L and P gene RNA by RT-qPCR from two black fly pools containing 13 and 20 S. bivittatum, consistent with previous studies implicating Simulium spp. as vectors of VSV [20]. Not surprisingly, the largest number of black flies were caught in traps on the two sites near running water (North Platte River and a spring-fed creek) providing a suitable larval fly habitat. S. bivittatum is in the subgenus Psilopelmia, which is the only subgenera of Simuliidae in North America that is still in need of taxonomic revision [32]. A better understanding of the distribution, biology, and taxonomy of species in the subgenus Psilopelmia could be critical to understanding the transmission and epidemiology of VS.

The overwintering and immature development of S. bivittatum in WY remains unstudied but should range between the known behaviors of individuals from Alberta, Canada, and Nebraska. In Canada, both larvae and pupae are found as late as September with an overwintering stage as eggs [46], and in Nebraska overwintering occurs as eggs with at least three generations per year from early April to late November [47]. Based on limited data from Utah, females of S. bivittatum lay around 200 eggs [48]. If virus overwintering occurs in flies, it is possibly from eggs laid in September, October, or later that hatch as larvae in the spring.

The P hypervariable sequence obtained from one black fly pool was $100 \%$ identical to virus isolated from the clinically infected equine index case on the same premises (NJ0806WYE) [38] and 99.3\% identical to two 2005 Wyoming isolates (NJ0805WYE and NJ0905WYB). The potential role of S. bivittatum in the overwintering of VSV from 2005 to 2006 remains unresolved as this collection was 11-12 days after lesions were reported at the premises, and spillover infection from a natural reservoir cannot be ruled out. However, black flies were clearly involved early in the outbreak with the overwintering genotype, as the sequence was identical to the first positive premises reported for the U.S. Neither positive pool contained engorged nor gravid females, which suggests active feeding of these flies on the infected horse occurred 2 to 6 days prior with a subsequent gonotrophic cycle and establishment of a productive infection prior to collection. This is the first report of VSV-positive S. bivittatum during an outbreak in WY and the first field evidence of possible VSV maintenance in black fly populations during an outbreak. Where and how the virus persisted in WY for nine months between the last 2005 case and the first 2006 case, in the absence of clinically infected animals, remains undetermined.

\section{Materials and Methods}

Insect collections. Insects were collected between 23-25 August on three premises with active VS horse cases in Natrona County near Casper, WY (Table 1). Biting flies were trapped at dusk using CDC light traps baited with dry ice. In a pasture site in east Casper near the North Platte River, proximal to the first confirmed VSV-positive horse with a lesion onset date of $13 \mathrm{Aug}$, six traps were set for two nights. In a field site near an artesian spring south of Casper, proximal to one confirmed positive horse with a lesion onset date of 15 Aug, two traps were set for one night and one trap was used for two additional nights. At a farm site southeast of Casper near a spring-fed creek, with one positive horse with a lesion onset date of 20 August, three traps were set for two nights. Trap positions were selected to include locations near infected animals, near feeding and drinking areas used by infected and uninfected animals, and near potential insect breeding sites. Traps were 
retrieved at dawn and the insects were killed with $\mathrm{CO}_{2}$. Insects were sorted and pooled by taxon (1-50 flies per pool) (Table 1) on a chill table. Biting flies were identified using morphological characters $[32,49,50]$. Grasshoppers were hand netted from pastures at the three locations, killed by freezing, sorted by morphological characters [51], and processed individually.

Real time RT-qPCR. Each biting fly pool was homogenized in $500 \mu \mathrm{L}$ of homogenization buffer $(20 \%$ fetal bovine serum, $50 \mu \mathrm{g} / \mathrm{mL}$ streptomycin, $50 \mathrm{U} / \mathrm{mL}$ penicillin, and $2.5 \mu \mathrm{g} / \mathrm{mL}$ amphotericin B in phosphate-buffered saline) [52] with gold-plated tungsten beads using a Tissue Lyser (Qiagen, Germantown, MD, USA) as previously described [53]. Total RNA was extracted from $400 \mu \mathrm{L}$ of each biting fly homogenate using an RNeasy kit (Qiagen) as per manufacturer's instruction and stored at $-80^{\circ} \mathrm{C}$. Individual grasshopper abdomens were homogenized in $1 \mathrm{~mL}$ of buffer [15] and total RNA was extracted from $900 \mu \mathrm{L}$ of the homogenate as above. All RNA extracts were initially screened for VSV using RT-qPCR for detection of the L gene as previously described [54]. Positive pool RNA was subsequently tested for the most variable region of the virus, the P gene, as previously described [55].

Virus isolations. Isolation of infectious VSV from RT-qPCR-positive pools was attempted by placing $60 \mu \mathrm{L}$ of the remaining $100 \mu \mathrm{L}$ insect homogenates in $600 \mu \mathrm{L}$ of antibiotic media $(400 \mathrm{U} / \mathrm{mL}$ penicillin, $400 \mu \mathrm{g} / \mathrm{mL}$ streptomycin, $200 \mu \mathrm{g} / \mathrm{mL}$ gentamicin, $25 \mu \mathrm{g} / \mathrm{mL}$ ciprofloxacin (Serologicals, Inc, Norcross, GA, USA), and $5 \mu \mathrm{g} / \mathrm{mL}$ amphotericin B prepared in Medium 199 with Earle's salts (M199-E; Sigma, St. Louis, MO, USA) in 10\% fetal bovine serum) [43]. An inoculum of $200 \mu \mathrm{L}$ per well (in triplicate) of a 6-well plate was added to Vero MARU (VM; Middle America Research Unit, Panama) cell monolayers with $2 \mathrm{~mL}$ M199-E (Sigma). Plates were incubated at $37{ }^{\circ} \mathrm{C}$ with $5 \% \mathrm{CO}_{2}$ and checked microscopically for CPE daily. After 7 days, plates were freeze-thawed twice, and samples were passed onto fresh VM cell monolayers. Cells were checked daily for CPE as above and after 7 days, RNA was extracted and tested for VSV L gene by RT-qPCR.

Sequencing. The extracted total RNA of insect pools testing positive for VSV L and $\mathrm{P}$ gene RNA by RT-qPCR was reverse transcribed with random hexamers and shipped to PIADC for sequencing. Amplicon generation of the hypervariable region (450 nt) of the P gene was performed using previously described primers [40]. Amplicons were cloned using the Zero Blunt TOPO PCR cloning kit (Invitrogen, Carlsbad, CA, USA). Positive clones were processed with the QuickLyse Miniprep kit (Qiagen) and bi-directionally sequenced with the M13 forward and reverse primers included in the Zero Blunt kit using a BigDye Terminator Sequencing kit on a 3730A automated sequencer (Applied Biosystems, Thermo Fisher Scientific, Waltham, MA, USA). The consensus sequence for the positive pool was deduced from a total of 12 clones using Sequencher software v4.8 (GeneCodes, Ann Arbor, MI, USA).

Phylogenetic analyses. The $\mathrm{P}$ gene hypervariable region sequence recovered from the black fly pool was aligned with other publicly available sequences from the 2004-2006 U.S. outbreak [38]. Sequences from Mexican isolates collected in 2000 were included as an outgroup. Redundant sequences were removed, and sequences were aligned using Clustal W implemented in MegaX [56]. The Tamura 3-parameter model with invariant sites was identified as the most appropriate model, and a maximum likelihood phylogenetic tree was constructed using this model and 100 bootstrap replicates implemented in MegaX. The final consensus tree was visualized in FigTree v1.4.3 (tree.bio.ed.ac.uk/software/figtree).

Author Contributions: Conceptualization, B.S.D., W.K.R., and K.E.B.; Data curation, B.S.D., W.K.R., K.E.B., S.J.P., and M.R.B.; Formal analysis, B.S.D., W.K.R., K.E.B., S.J.P., and M.R.B.; Funding acquisition, B.S.D. and L.L.R.; Investigation, B.S.D., W.K.R., and K.E.B.; Methodology, B.S.D., W.K.R., and K.E.B.; Project administration, B.S.D.; Resources, B.S.D. and L.L.R.; Supervision, B.S.D., W.K.R., K.E.B., and L.L.R.; Validation, B.S.D., W.K.R., and K.E.B.; Visualization, B.S.D., W.K.R., and K.E.B.; Writing-original draft, B.S.D., W.K.R., and K.E.B.; Writing-review and editing, B.S.D., W.K.R., K.E.B., S.J.P., M.R.B., and L.L.R. All authors have read and agreed to the published version of the manuscript. 
Funding: This research was funded by USDA, ARS, NP103 Animal Health National Program, Project Numbers 3020-32000-013-00D and 8064-32000-059-00D.

Institutional Review Board Statement: Not applicable.

Informed Consent Statement: Not applicable.

Data Availability Statement: The data presented in this study are available upon request from the corresponding authors and through the USDA, Agricultural Research Information System.

Acknowledgments: We thank W. Yarnell and M. Stuart for their valuable assistance with field and laboratory research. We thank W. Grogan and P.H. Adler for verification of Culicoides and Simulium spp. We thank S. Schell for assistance with grasshopper identifications. We thank A. PelzelMcCluskey for providing critical information on APHIS VS case reports. Mention of trade names or commercial products in this publication is solely for the purpose of providing specific information and does not imply recommendation or endorsement by the U.S. Department of Agriculture. The conclusions in this report are those of the authors and do not necessarily represent the views of the USDA. The USDA is an equal opportunity provider and employer.

Conflicts of Interest: The authors declare no conflict of interest.

\section{References}

1. Reis, J.L.; Mead, D.; Rodriguez, L.L.; Brown, C.C. Transmission and pathogenesis of vesicular stomatitis virus. Braz. J. Vet. Pathol. 2009, 2, 49-58.

2. Letchworth, G.; Rodriguez, L.; Del Cbarrera, J. Vesicular Stomatitis. Vet. J. 1999, 157, 239-260. [CrossRef]

3. Rodríguez, L.L. Emergence and re-emergence of vesicular stomatitis in the United States. Virus Res. 2002, 85, 211-219. [CrossRef]

4. Kitching, I.J. List A Disease as a Constraint to International Trade. Ann. N. Y. Acad. Sci. 2000, 916, 50-54. [CrossRef]

5. Toms, D.; Powell, M.; Redlinger, M.; Beach, T.; Jenkins-Moore, M.; Buffington, T.; Harding, C.; Swenson, S. Monitoring of Four Naturally Infected Horses for Vesicular Stomatitis Antibody. In Proceedings of the Annual Meeting of the American Association of Veterinary Laboratory Diagnosticians, Greensboro, NC, USA, 20 October 2012.

6. Pelzel-McCluskey, A.M.; Animal Population Health Institute (APHI), Fort Collins, CO, USA. Duration of vesicular stomatitis virus antibody in horses. Personal communication, 2021.

7. USDA-APHIS. 2020 Vesicular Stomatitis Virus (VSV) Situation Report-August 6, 2020; USDA-APHIS: Riverdale Park, MD, USA, 2020; pp. 1-8.

8. Stallknecht, D.E.; Howerth, E.W.; Reeves, C.L.; Seal, B.S. Potential for contact and mechanical vector transmission of vesicular stomatitis virus New Jersey in pigs. Am. J. Vet. Res. 1999, 60, 43-48.

9. Mead, D.D.; Howerth, E.W.; Murphy, M.D.; Gray, E.W.; Roblet, R.; Stallknecht, D.E. Black Fly Involvement in the Epidemic Transmission of Vesicular Stomatitis New Jersey Virus (Rhabdoviridae: Vesiculovirus). Parasites Vectors 2004, 4, 351-358. [CrossRef]

10. Francy, D.B.; Moore, C.G.; Smith, G.C.; Jakob, W.L.; Taylor, S.A.; Calisher, C.H. Epizoötic Vesicular Stomatitis in Colorado, 1982: Isolation of Virus from Insects Collected Along the Northern Colorado Rocky Mountain Front Range. J. Med. Entomol. 1988, 25, 343-347. [CrossRef] [PubMed]

11. Rozo-Lopez, P.; Drolet, B.S.; Londoño-Renteria, B. Vesicular Stomatitis Virus Transmission: A Comparison of Incriminated Vectors. Insects 2018, 9, 190. [CrossRef]

12. Comer, J.A.; Tesh, R.B.; Modi, G.B.; Corn, J.L.; Nettles, V.F. Vesicular Stomatitis Virus, New Jersey Serotype: Replication in and Transmission by Lutzomyia shannoni (Diptera: Psychodidae). Am. J. Trop. Med. Hyg. 1990, 42, 483-490. [CrossRef] [PubMed]

13. Mead, D.G.; Cupp, E.W.; Mare, C.J. Vector Competence of Select Black Fly Species for Vesicular Stomatitis Virus (New Jersey Serotype). Am. J. Trop. Med. Hyg. 1997, 57, 42-48. [CrossRef] [PubMed]

14. Mead, D.G.; Maré, C.J.; Ramberg, F.B. Bite Transmission of Vesicular Stomatitis Virus (New Jersey Serotype) to Laboratory Mice by Simulium vittatum (Diptera: Simuliidae): Table 1. J. Med. Entomol. 1999, 36, 410-413. [CrossRef] [PubMed]

15. Nunamaker, R.A.; Lockwood, J.A.; Stith, C.E.; Campbell, C.L.; Schell, S.P.; Drolet, B.S.; Wilson, W.C.; White, D.M.; Letchworth, G.J. Grasshoppers (Orthoptera: Acrididae) could serve as reservoirs and vectors of vesicular stomatitis virus. J. Med. Entomol. 2003, 40, 957-963. [CrossRef] [PubMed]

16. Nunamaker, R.A.; De León, A.A.P.; Campbell, C.L.; Lonning, S.M. Oral infection of Culicoides sonorensis (Diptera: Ceratopogonidae) by vesicular stomatitis virus. J. Med. Entomol. 2000, 37, 784-786. [CrossRef] [PubMed]

17. Drolet, B.S.; Campbell, C.L.; Stuart, M.A.; Wilson, W.C. Vector competence of Culicoides sonorensis (Diptera: Ceratopogonidae) for vesicular stomatitis virus. J. Med. Entomol. 2005, 42, 409-418. [CrossRef] [PubMed]

18. de Leon, A.A.P.; O'Toole, D.; Tabachnick, W.J. Infection of guinea pigs with vesicular stomatitis New Jersey virus Transmitted by Culicoides sonorensis (Diptera: Ceratopogonidae). J. Med. Entomol. 2006, 43, 568-573. [CrossRef]

19. de Leon, A.A.P.; Tabachnick, W.J. Transmission of vesicular stomatitis New Jersey virus to cattle by the biting midge Culicoides sonorensis (Diptera: Ceratopogonidae). J. Med. Entomol. 2006, 43, 323-329. [CrossRef] 
20. Schmidtmann, E.T.; Tabachnick, W.J.; Hunt, G.J.; Thompson, L.H.; Hurd, H.S. 1995 Epizootic of Vesicular Stomatitis (New Jersey Serotype) in the Western United States: An Entomologic Perspective. J. Med. Entomol. 1999, 36, 1-7. [CrossRef] [PubMed]

21. Sudia, W.D.; Fields, B.N.; Calisher, C.H. The Isolation of Vesicular Stomatitis Virus (Indiana Strain) and Other Viruses from Mosquitoes in New Mexico, 1965. Am. J. Epidemiol. 1967, 86, 598-602. [CrossRef]

22. Walton, T.E.; Moore, C.G.; Smith, G.C.; Holbrook, F.R.; Schiefer, T.J.; Janney, G.C.; Jones, R.H.; Kramer, W.L.; Webb, P.A.; Davis, T. Epizootic Vesicular Stomatitis in Colorado, 1982: Epidemiologic and Entomologic Studies. Am. J. Trop. Med. Hyg. 1987, 36, 166-176. [CrossRef]

23. Kramer, W.L.; Jones, R.H.; Holbrook, F.R.; Walton, T.E.; Calisher, C.H. Isolation of Arboviruses from Culicoides Midges (Diptera: Ceratopogonidae) in Colorado During an Epizootic of Vesicular Stomatitis New Jersey. J. Med. Entomol. 1990, $27,487-493$. [CrossRef] [PubMed]

24. Corn, J.L.; Comer, J.A.; Erickson, G.A.; Nettles, V.F. Isolation of Vesicular Stomatitis Virus New Jersey Serotype from Phlebotomine Sand Flies in Georgia. Am. J. Trop. Med. Hyg. 1990, 42, 476-482. [CrossRef]

25. Shelokov, A.; Peralta, P.H. Vesicular stomatitis virus, Indiana type: An arbovirus infection of tropical sandflies and humans? Am. J. Epidemiol. 1967, 86, 149-157. [CrossRef]

26. Stallknecht, D.E. VSV-NJ on Ossabaw Island, Georgia. The truth is out there. Ann. N. Y. Acad. Sci. 2000, 916, 431-436. [CrossRef]

27. Drolet, B.S.; Stuart, M.A.; Derner, J. Infection of Melanoplus sanguinipes Grasshoppers following Ingestion of Rangeland Plant Species Harboring Vesicular Stomatitis Virus. Appl. Environ. Microbiol. 2009, 75, 3029-3033. [CrossRef] [PubMed]

28. Cupp, E.W.; Maré, C.J.; Cupp, M.S.; Ramberg, F.B. Biological Transmission of Vesicular Stomatitis Virus (New Jersey) By Simulium vittatum (Diptera: Simuliidae). J. Med. Entomol. 1992, 29, 137-140. [CrossRef]

29. Mead, D.G.; Ramberg, F.B.; Maré, C.J. Laboratory vector competence of black flies (Diptera:Simuliidae) for the Indiana serotype of vesicular stomatitis virus. Ann. N. Y. Acad. Sci. 2006, 916, 437-443. [CrossRef] [PubMed]

30. Mead, D.G.; Gray, E.W.; Noblet, R.; Murphy, M.D.; Howerth, E.W.; Stallknecht, D.E. Biological Transmission of Vesicular Stomatitis Virus (New Jersey Serotype) bySimulium vittatum (Diptera: Simuliidae) to Domestic Swine (Sus scrofa). J. Med. Entomol. 2004, 41, 78-82. [CrossRef] [PubMed]

31. Mead, D.G.; Lovett, K.R.; Murphy, M.D.; Pauszek, S.J.; Smoliga, G.; Gray, E.W.; Noblet, R.; Overmyer, J.; Rodriguez, L.L. Experimental Transmission of Vesicular Stomatitis New Jersey Virus From Simulium vittatum to Cattle: Clinical Outcome Is Influenced by Site of Insect Feeding. J. Med. Entomol. 2009, 46, 866-872. [CrossRef] [PubMed]

32. Adler, P.H.; Currie, D.C.; Woods, D.M.; Idema, R.M.; Zettler, L.W. The Black Flies (Simuliidae) of North America; Cornell University Press: Ithaca, NY, USA, 2004.

33. Adler, P.H.; McCreadie, J.W. Black Flies (Simuliidae). In Medical and Veterinary Entomology, 3rd ed.; Mullen, G.R., Durden, L.A., Eds.; Elsevier Inc.: Amsterdam, The Netherlands, 2019; pp. 237-259.

34. Peck, D.E.; Reeves, W.K.; Pelzel-McCluskey, A.M.; Derner, J.D.; Drolet, B.; Cohnstaedt, L.W.; Swanson, D.; McVey, D.S.; Rodriguez, L.L.; Peters, D.P. Management Strategies for Reducing the Risk of Equines Contracting Vesicular Stomatitis Virus (VSV) in the Western United States. J. Equine Vet. Sci. 2020, 90, 103026. [CrossRef] [PubMed]

35. Townsend, L.H.; Turner, E.C.; Allen, W.A. An assessment of feeding damage threshold of Simulium vittatum, a black fly pest of horses in Virginia. Mosquito News. Mosq. News 1977, 37, 742-744.

36. USDA-APHIS. Vesicular Stomatitis Surveillance-2005 Final Summary; USDA-APHIS: Riverdale Park, MD, USA, 2005.

37. Timoney, P.J. Committee on Infectious Diseases of Horses: Report of the Committee. In Proceedings of the United States Animal Health Association, Minneapolis, MN, USA, 15 October 2006; pp. 333-335.

38. Perez, A.M.; Pauszek, S.J.; Jimenez, D.; Kelley, W.N.; Whedbee, Z.; Rodriguez, L.L. Spatial and phylogenetic analysis of vesicular stomatitis virus over-wintering in the United States. Prev. Vet. Med. 2010, 93, 258-264. [CrossRef]

39. Cook, W. Vesicular Stomatitis in Wyoming; University of Wyoming: Laramie, WY, USA, 2006.

40. Rainwater-Lovett, K.; Pauszek, S.J.; Kelley, W.N.; Rodriguez, L.L. Molecular epidemiology of vesicular stomatitis New Jersey virus from the 2004-2005 US outbreak indicates a common origin with Mexican strains. J. Gen. Virol. 2007, 88, 2042-2051. [CrossRef]

41. Tesh, R.B.; Chaniotis, B.N.; Johnson, K.M. Vesicular stomatitis virus (Indiana serotype): Transovarial transmission by phlebotomine sandlies. Science 1972, 175, 1477-1479. [CrossRef] [PubMed]

42. Comer, J.A.; Kavanaugh, D.M.; Stallknecht, D.E.; Corn, J.L. Population Dynamics of Lutzomyia shannoni (Diptera: Psychodidae) in Relation to the Epizootiology of Vesicular Stomatitis Virus on Ossabaw Island, Georgia. J. Med. Entomol. 1994, $31,850-854$. [CrossRef] [PubMed]

43. Rozo-Lopez, P.; Londono-Renteria, B.; Drolet, B.S. Venereal Transmission of Vesicular Stomatitis Virus by Culicoides sonorensis Midges. Pathogens 2020, 9, 316. [CrossRef] [PubMed]

44. Palinski, R.M.; Pauszek, S.J.; Burruss, N.D.; Savoy, H.; Humphreys, J.; Pelzel-McCluskey, A.M.; Arzt, J.; Peters, D.P.C.; Rodriguez, L.L. Vesicular Stomatitis Virus Strain NJ0806WYE Nucleocapsid, Phosphoprotein, Matrix, Glycoprotein, and Polymerase Genes, Complete Cds; USDA-APHIS: Riverdale Park, MD, USA, 2020.

45. Mead, D.G.; Ramberg, F.B.; Besselsen, D.G.; Maré, C.J. Transmission of Vesicular Stomatitis Virus from Infected to Noninfected Black Flies Co-Feeding on Nonviremic Deer Mice. Science 2000, 287, 485-487. [CrossRef] [PubMed]

46. Currie, D.C. An annotated list of and keys to the immagure black flies of Alberta (Diptera: Simuiliidae). Mem. Entomol. Soc. Can. 1986, 134, 1-90. 
47. Pruess, K.P.; Peterson, B.V. The black flies (Diptera: Simuliidae) of Nebraska: An annotated list. J. Kans. Entomol. Soc. 1987, 60, 528-534.

48. Peterson, B.V. Observations on Mating, Feeding, and Oviposition of Some Utah Species of Black Flies (Diptera: Simuliidae). Can. Entomol. 1959, 91, 147-155. [CrossRef]

49. Wirth, W.W.; Dyce, A.L.; Peterson, B.V. An Atlas of Wing Photographs with a Summary of the Numerical Characters of the Nearctic Species of Culicoides (Diptera: Ceratopogonidae). Environ. Monit. Asses. 1985, 129, 413-420.

50. Darsie, R.F.; Ward, R.A. Identification and Geographical Distribution of the Mosquitoes of North America, North of Mexico; University Press of Florida: Gainesville, FL, USA, 2004.

51. Pfadt, R.E. Grasshoppers of Wyoming and the West. In Field Guide to Common Western Grasshoppers; University of Wyoming: Laramie, WY, USA, 1994.

52. Shi, P.-Y.; Kauffman, E.B.; Ren, P.; Felton, A.; Tai, J.H.; Dupuis, A.P.; Jones, S.A.; Ngo, K.A.; Nicholas, D.C.; Maffei, J.; et al. High-Throughput Detection of West Nile Virus RNA. J. Clin. Microbiol. 2001, 39, 1264-1271. [CrossRef] [PubMed]

53. Kato, C.Y.; Mayer, R.T. An improved, high-throughput method for detection of bluetongue virus RNA in Culicoides midges utilizing infrared-dye-labeled primers for reverse transcriptase PCR. J. Virol. Methods 2007, 140, 140-147. [CrossRef] [PubMed]

54. Hole, K.; Clavijo, A.; Pineda, L.A. Detection and Serotype-Specific Differentiation of Vesicular Stomatitis Virus Using a Multiplex, Real-Time, Reverse Transcription-Polymerase Chain Reaction Assay. J. Vet. Diagn. Investig. 2006, 18, 139-146. [CrossRef] [PubMed]

55. Wilson, W.C.; Letchworth, G.J.; Jiménez, C.; Herrero, M.V.; Navarro, R.; Paz, P.; Cornish, T.E.; Smoliga, G.; Pauszek, S.J.; Dornak, C.; et al. Field Evaluation of a Multiplex Real-Time Reverse Transcription Polymerase Chain Reaction Assay for Detection of Vesicular Stomatitis Virus. J. Vet. Diagn. Investig. 2009, 21, 179-186. [CrossRef] [PubMed]

56. Kumar, S.; Stecher, G.; Li, M.; Knyaz, C.; Tamura, K. MEGA X: Molecular Evolutionary Genetics Analysis across Computing Platforms. Mol. Biol. Evol. 2018, 35, 1547-1549. [CrossRef] 